\title{
PENGARUH MODEL SELF DIRECTED LEARNING TERHADAP HASIL BELAJAR SISWA PADA MATA PELAJARAN EKONOMI
}

\author{
Ajeng Ayu Novelia Sidmewa ${ }^{1}$, Yuyun Susanti ${ }^{2}$, Rizka Andhika Putra ${ }^{3}$ \\ 1,2,3 Program Studi Pendidikan Akuntansi, Universitas Galuh, Jl. R. E. Martadinata No.150, Ciamis, Indonesia \\ E-mail: ayuajeng477@gmail.com, Yuyunsusanti444@gmail.com
}

\begin{abstract}
Low learning outcomes are a problem in this study, because learning outcomes are one of the benchmarks for the success of the learning process, educators are required to immediately seek various efforts to achieve success, low learning outcomes are motivated by various factors including the selection of the right learning model used by educators, The research method used is the experimental method of Quasi Experimental Nonequivalent Control Group Design using the formula N-Gain = (posttest score - pretest score) divided by (maximum score - pretest score), while to measure differences in student learning outcomes using the t test. Based on the results of the research that has been carried out, it can be seen: 1) There are differences in the learning outcomes of students who use the Independent learning model (Self Directed Learning) in the initial measurement (pretest) of 32.5 and the final measurement (posttest) of 87.75 with the average N-Gain is 0.82 in the high category. 2) There are differences in the learning outcomes of students who get conventional learning models at the initial measurement (pretest) of 32 and the final measurement (posttest) of 82.4 with an average N-Gain of 0.73 in the high category. 3) There are differences in the learning outcomes of students who get the Independent learning model (Self Directed Learning) with those who use the conventional learning model (lecture) in the final measurement (posttest) based on the $t$-test, it is obtained $t_{\text {count }}>t_{\text {tabel }}$, namely $5.24>t_{\text {table }} 1.67$ with a significance level of $5 \%$ and $d k$ of 69 .
\end{abstract}

Keywords: Self-Directed Learning Model, Learning Outcomes.

\section{ABSTRAK}

Rendahnya hasil belajar merupakan masalah dalam penelitian ini, karena hasil belajar merupakan salah satu tolak ukur keberhasilan proses pembelajaran, maka pendidik dituntut untuk segera mencari berbagai upaya untuk mencapai keberhasilan, rendahnya hasil belajar dilatarbelakangi oleh berbagai faktor diantaranya pemilihan model pembelajaran yang tepat digunakan oleh pendidik, Model Pembelajaran Mandiri pada pengukuran akhir. Metode penelitian yang digunakan adalah metode eksperimen desain Quasi Eksperimental Nonequivalent Control Group Design dengan menggunakan rumus $N$-Gain $=$ (skor posttest - skor pretest) dibagi dengan (skor maksimum -skor pretest), sedangkan untuk mengukur perbedaan hasil belajar peserta didik menggunakan uji t. Berdasarkan hasil penelitian yang telah dilakukan, maka dapat diketahui: Terdapat perbedaan hasil belajar peserta didik yang 1) menggunakan model pembelajaran Mandiri pada pengukuran awal sebesar 32,5 dan pengukuran akhir sebesar 87,75 dengan pengukuran awal (pretest) sebesar 32 dan pengukuran akhir (posttest) sebesa $r$ 82,4 dengan rata-rata N-Gain bernilai 0,73 dengan kategori tinggi. 3) mendapatkan model pembelajaran Mandiri (Self Directed Learning)dengan yang menggunakan model pembelajaran konvensional (ratarata N-Gain bernilai 0,82 dengan kategori tinggi. 2) mendapatkan model pembelajaran konvensional pada ceramah) pada pengukuran akhir (posttest) berdasarkan uji $t$-test diperoleh thitung $>t_{\text {tabel }}$, yaitu 5,24 $>t_{\text {tabel }} 1,67$ dengan taraf signifikansi $5 \%$ dan dk sebesar 69.

Kata Kunci : Model Pembelajaran Mandiri (Self Directed Learning), Hasil Belajar.

Cara sitasi: Sidmewa, A.A.N., Susanti, Y., \& Putra, R. A. (2021). Pengaruh Model PembelajaranSelf Directed Learning Terhadap Hasil Belajar Siswa Pada Mata Pelajaran Ekonomi. J-KIP (Jurnal Keguruan dan IImu Pendidikan), 2(3), 197-206. 


\section{PENDAHULUAN}

Pendidikan merupakan hal penting dalam rangka meningkatkan kualitas Sumber Daya Manusia baik dari segi spiritual, intelegensi, maupun skill untuk menunjang kehidupannya (Sopiah, Effendi \& Sunaryo, 2020). Dalam pendidikan ada yang disebut dengan hasil belajar. Menurut Sudjana (2016) Hasil belajar adalah kemampuan yang dimiliki siswa setelah ia menerima pengalaman belajarnya. Rendahnya hasil belajar siswa biasanya dapat disebabkan oleh beberapa faktor, Menurut Slameto (2018) mengemukakan faktor- faktor yang mempengaruhi hasil belajar dapat digolongkan menjadi 2 golongan yaitu faktor intern dan faktor ekstern. Faktor internal yaitu yang berasal dari diri sendiri, misalnya minat dan motivasi belajar siswa yang rendah. Faktor eksternal yaitu yang berasal dari luar atau lingkungan, misalnya masalah dalam keluarga dapat menyebabkan hasil belajar siswa yang rendah. Keberhasilan proses pembelajaran merupakan aktivitas yang dilakukan oleh guru dan siswa. Namun kenyataannya hamper setiap sekolah mengalami permasalahan dengan tingkat keberhasilan hasil belajar yang rendah, terlihat dari peserta didik yang masih banyak nilainya di bawah KKM (Kriteria Ketuntasan Minimun).

Upaya yang dapat dilakukan dalam mengatasi permasalahan dalam pembelajaran salah satunya dengan menerapkan model pembelajaran yang sesuai dengan karakteristik peserta didik dan juga materi pelajaran yang akan diajarkan.. Salah satu model pembelajaran dengan gaya yang berbeda adalah model pembelajaran Mandiri (Self Directed Learning). Belajarmerupakansuatu proses perubahan sikap dan perilaku yang berdasarkan pengetahuan dan pengalama pendapat tersebut didukung oleh penjelasan Slameto (2010) "Belajar adalah suatu proses usaha yang dilakukan seseorang untuk memperoleh suatu perubahan tingkah laku yang baru secara keseluruhan sebagai hasil pengalamannya sendiri dalam berinteraksi dengan lingkungannya.

Model pembelajaran Mandiri (Self Directed Learning) merupakan pembelajaran yang mengajak siswa melakukan pembelajaran sendiri atau kelompok. Tindakan ini dirancang untuk menghubungkan pengetahuan akademik dengan kehidupan sehari-hari untuk mencapai tujuan yang maksimal. Strategi pembelajaran mandiri (Self Directed Learning) adalah untuk membangun inisiatif individu, kemandirian, peningkatan diri. Model pembelajaran Mandiri (Self Directed Learning) bisa dilakukan dengan teman atau kelompok.Model Pembelajaran Mandiri (Self Directed Learning) adalah salah satu model pembelajaran yang dapat meningkatkan hasil belajar dan dapat mengembangkan potensi siswa karena model pembelajaran ini membebaskan siswa untuk menentukan model pembelajaran apa yang akan mereka laksanakan.

Berdasarkan hasil observasi di SMAN 1 Cisaga bahwa proses pembelajaran di kelas $\mathrm{X}$ masih menggunakan metode konvensional yaitu ceramah sehingga memberikan suasana pembelajaran yang jenuh dan tidak menarik siswa. Hal ini terlihat pada hasil ulangan harian siswa yang masih rendah atau tidak tuntas. Dikarenakan model pembelajaran yang masih digunakan kurang partisipatif dan juga siswa yang kurang memperhatikan materi yang di sampaikan selama proses pembelajaran yang berakibat pada proses hasil belajar yang belum optimal sehingga tingkat ketuntasan masih rendah. Berikut ini merupakan data awal rata rata ulangan harian pada mata pelajaran Ekonomi:

Tabel 1. Nilai Ulangan Harian Kelas X IPS SMA Negeri 1 Cisaga

\begin{tabular}{ccccccccc}
\hline \multirow{2}{*}{ No } & Kelas & Jumlah Siswa & KKM & Tertinggi & Terendah & Rata Rata & Jumlah Ketuntasan Siswa & TidakTuntas \\
\hline 1 & X IPS 1 & 36 & 75 & 93 & 70 & 72,58 & 16 & 20 \\
2 & X IPS 2 & 35 & 75 & 90 & 70 & 60,62 & 16 & 19 \\
& \multicolumn{8}{c}{ Jumlah tuntas dan tidak tuntas } \\
\multicolumn{4}{c}{ Jumlah \% ketuntasan } & & & 32 & 39 \\
\hline
\end{tabular}

Sumber: SMA Negeri 1 Cisaga

Berdasarkan tabel diatas dapat diketahui informasi bahwa kelas X di SMAN 1 Cisaga terdapat 2 kelas dengan jumlah 71 siswa, pada kolom presentase ketuntasan terdapat 45,07\% hasil belajar siswa 
yang tidak tuntas dan hanya $54,93 \%$ siswa yang tuntas. Apabila dilihat dari rata rata nilai Ulangan Harian mata pelajaran Ekonomi pada setiap kelasnya masih banyak siswa yang belum mencapai Kriteria Ketuntasan Minimum (KKM).

Nilai KKM untuk mata pelajaran Ekonomi di SMAN 1 Cisaga adalah 75. Jumlah siswa yang mendapatkan nilai diatas KKM sebanyak 32 orang siswa dan sisanya 39 orang mendapatkan nilai dibawah KKM. Rendahnya hasil belajar siswa menunjukkan bahwa daya serap siswa terhadap mata pelajaran Ekonomi pada kelas $\mathrm{X}$ masih kurang efektif.

Harsono (2012) menyatakan bahwa "self directed learning (SDL) diartikan sebagai pembelajaran yang berpusat pada peserta didik (studentcentred approach) di mana proses dan pengalaman belajar diatur dan dikontrol oleh peserta didik sendiri".

Idealnya setelah pembelajarandenganmenggunakan model pembelajaranmandiri siswa memiliki kemampuan untuk mendemontrasikan pemahamannya dan kemampuan pemecahan masalah seputar konsep-konsep pada pokok bahasan yang menjadi cakupan kurikulum. Aktivitas belajar siswa selama menjalani proses pembelajaran yang dapat diamati dan nilai akhir yang diperolehnya mencerminkan tingkat kemampuan pemahaman dan pemecahan masalah mahasiswa. Namun, hasil belajar yang mencerminkan tingkat kemampuan pemahaman dan pemecahan masalah siswa belum menunjukkan hasil yang optimal. Hasil belajar yang diperoleh siswa untuk 2 bulan terakhir dengan pembelajaran menggunakan metode Mandiri (Self Directed Learning) mengalami peningkatan yang awal mulanya rata-rata 32,5 meningkat menjadi 87,75 .

Berdasarkan hasil observasi terhadap pembelajaran yang berlangsung selama ini terungkap beberapa faktor penyebab munculnya permasalahan tersebut. Faktor-faktor tersebut adalah: (1) partisipasi siswa yang kurang dalam pembelajaran (2) motivasi siswa yang masih rendah; dan 3) masalah keluarga yang menyebabkan motivasi siswa dalam belajar kurang. Upaya yang dapat dilakukan dalam mengatasi permasalahan dalam pembelajaran salah satunya dengan menerapkan model pembelajaran yang sesuai dengan karakteristik peserta didik dan juga materi pelajaran yang akan diajarkan

Menurut Sunarto (dalam Beratha, 2009) menyatakan bahwa selfdirected learning (SDL) dapat diartikan sebagai usaha individu untuk melakukan kegiatan belajar secara sendiri maupun dengan bantuan orang lain berdasarkan motivasinya sendiri untuk menguasai suatu materi atau kompetensi tertentu sehingga dapat digunakannya untuk memecahkan masalah yang dijumpai di dunia nyata. SDL menyadarkan dan memberdayakan siswa bahwa belajar adalah tanggung jawab mereka sendiri, di mana proses belajar yang dilakukan berpusat pada siswa (student centered)

Hal yang terpenting dalam proses belajar mandiri adalah peningkatan kemauan dan keterampilan siswa dalam proses belajar tanpa bantuan orang lain, sehingga siswa pada akhirnya siswa tidak bergantung pada guru, pembimbing, teman, atau orang lain dalam belajar. Siswa akan berusaha sendiri dahulu untuk memahami isi pelajaran yang dibaca atau dilihatnya. Jika mendapat kesulitan barulah bertanya atau mendiskusikannya dengan teman atau guru. Cole \& Chan (dalam Beratha, 2009) menyatakan bahwa melalui pembelajaran secara mandiri, siswa akan meningkatkan kemampuan belajarnya, mulai dari tingkatan yang paling sederhana (bertanya pada diri sendiri dan menjawabnya) sampai pada merencanakan, mengendalikan, dan menilai sendiri hasil belajarnya. Belajar mandiri bukan berarti belajar sendiri. Seringkali orang menyalah artikan belajar mandiri sebagai belajar sendiri. Belajar mandiri berarti belajar secara berinisiatif, dengan ataupun tanpa bantuan orang lain dalam belajar.

Konsep Belajar Mandiri (self-directed Learning) sebenarnya berakar dari konsep pendidikan orang dewasa. Namun belajar mandiri juga cocok untuk semua tingkatan usia. Dengan kata lain, belajar mandiri sesuai untuk semua jenjang sekolah baik untuk sekolah menengah maupun sekolah dasar dalam rangka meningkatkan prestasi dan kemampuan siswa. Pembelajaran mandiri didefinisikan sebagai proses belajar yang mengajak siswa melakukan tindakan mandiri yang melibatkan terkadang satu orang, biasanya satu kelompok. Tindakan mandiri ini dirancang untuk menghubungkan 
pengetahuan akademik dengan kehidupan siswa sehari-hari secara sedemikian rupa untuk mencapai tujuan yang bermakna.

Menurut Rusman (2012) jenis-jenis bahan belajar mandiri yaitu modul, content berbasis web. Pembelajaran mandiri membebaskan siswa untuk belajar sesuai dengan gaya belajar mereka sendiri, sesuai dengan kecepatan belajar mereka dan sesuai dengan arah minat dan bakat mereka dalam menggunakan kecerdasan majemuk yang mereka miliki. Berdasarkan pemaparan di atas, maka dipandang perlu diadakan penelitian tentang pengaruh model pembelajaran self directed learning terhadap hasil belajar pada mata pelajaran ekonomi di SMA Negeri 1 Cisaga.

Tujuan dari pelaksanaan penelitian ini adalah sebagai berikut: untuk mengetahui

1. Perbedaan hasil belajar peserta didik yang menggunakan Model Pembelajaran Mandiri (Self Directed Learning) pada pengukuran awal (pretest) dan pengukuran akhir (posttest)

2. Perbedaan hasil belajar siswa yang menggunakan Model Pembelajaran Mandiri (Self Directed Learning) dibandingkan dengan metode konvensional pada pengukuran tes awal (pretest) dan pengukuran tes akhir (posttest)

3. Perbedaan hasil belajar siswa menggunakan Model Pembelajaran Mandiri (Self Directed Learning) pada pengukuran akhir (posttest).

\section{METODE PENELITIAN}

Berhasil atau tidaknya suatu penelitian ditentukan oleh metode penelitian. Sugiyono (2016) menyatakan bahwa "Metode penelitian dapat diartikan sebagai cara ilmiah untuk mendapatkan data yang valid dengan tujuan dapat ditemukan, dikembangkan dan dibuktikan, suatu pengetahuan tertentu sehingga dapat digunakan untuk memahami,memecahkan dan mengantisipasi masalah dalam bidang pendididkan"..

Untuk meneliti masalah peneliti menggunakan metode eksperimen. Sugiyono (2016) menyatakan bahwa "Metode penelitian eksperimen dapat diartikan sebagai metode penelitian yang digunakan untuk mencari pengaruh perlakuan tertentu terhadap yang lain dalam kondisi yang dikendalikan". Metode eksperimen merupakan salah satu metode penelitian kuantitatif. Dalam penelitian ini peneliti menggunakan bentuk penelitian jenis Quasi Eksperimen dengan design Nonequivalen Group Design. Peneliti membagi kelas menjadi dua yaitu kelas eksperimen dan kelas kontrol. Selanjutnya kelas tersebut diberikan pretest untuk mengukur dan mengetahui kemampuan awal peserta didik, selanjutnya setelah diberikan prestest, kelas eksperimen diberikan perlakuan dengan menggunakan model pembelajaran mandiri (self directed learning), sedangkan kelas control diberikan perlakuan dengan menggunakan metode konvensial.

Setelah diberikan perlakuan kepada kedua kelas maka selanjutnya diberikan posttest untuk mengatahui pengaruh apakah ada perbedaan hasil belajar peserta didik pada mata pelajaran Ekonomi dengan menggunakan model mandir (self directed learning) pada kelas eksperimen, dan metode konvensional pada kelas kontrol. Langkah-Langkah penerapan model pembelajaran mandiri adalah sebagai berikut:

1. Perencanaan (planning), siswa merencanakan aktivitas pada tempat dan waktu di mana siswa merasa nyaman untuk belajar. Siswa juga merencanakan komponen belajar yang diinginkan serta menentukan target belajar yang ingin dicapai.

2. Pada tahap monitoring, siswa mengamati dan mengobservasi pembelajaran mereka. Banyak tantangan belajar yang dapat ditemukan oleh siswa ketika siswa memonitor pelajaran mereka sehingga akan menjadikan proses belajar yang lebih bermakna.

3. Dalam tahap evaluasi, siswa mengevaluasi pelajaran dan pengetahuan yang dimiliki kemudian guru memberikan umpan balik serta mengkolaborasikan pengetahuan siswa yang satu dengan yang lainnya untuk mencapai suatu pemahaman yang benar.

Teknik analisis yang digunakan dalam penelitianinidengan menggunakan langkah-langkah diantaranya, Uji Instrument Penelitian, Prasyarat Uji Ststistika dan Uji analisis data. Sugiyono (2016) 
menyatakan bahwa "Instrumen penelitian adalah suatu alat yang digunakan mengukur fenomena alam maupun sosial yang diamati secara spesifik semua fenomena ini disebut variable penelitian". Instrumen yang digunakan untuk memperoleh data akan dilakukan pengujian terlebih dahulu dengan melakukan uji instrumen berikut:

1. Uji Validitas Rumus yang dapat digunakan untuk mengetahui validitas soal tes adalah dengan teknik korelasi product moment

2. Uji Reliabilitas untuk menguji reliabilitas dapat menggunakan berbagai metode, namun dalam penelitian ini metode yang digunakan adalah dengan penggunaan rumus K-R. 20

3. Analisis butir soal diantaranya uji taraf kesukaran, dan uji daya pembeda.

Dalam pengujian hipotesis yang diuraikan oleh penulis terdapat dua kemungkinan, yaitu $\mathrm{Ho}$ dan Ha. Ho merupakan istilah untuk hipotesis nol, sedangkan Ha merupakan istilah untuk hipotesis alternative. Dua kemungkinan tersebut adalah:

1. Ha diterima dan Ho ditolak jika $t_{\text {hitung }}>t_{\text {tabel }}$ artinya terdapat perbedaan hasil belajar peserta didik.

2. Ho diterima dan Ha ditolak jika $t_{\text {hitung }}<t_{\text {tabel }}$ artinya tidak terdapat perbedaan hasil belajar peserta didik.

\section{HASIL DAN PEMBAHASAN}

Merurut Knowles (dalam Sunarto, 2008) mengajukan enam tahap self directed learning. Deskripsi dari keenam tahap SDL oleh Knowles ini meliputi:a) setting suasana belajar, b) diagnosis kebutuhan dalam pembelajaran,c) perumusan tujuan pembelajaran, d) identifikasi kemampuan pebelajar dan sumber belajar di dalam pembelajaran, e) implementasi dan pemilihan strategi belajar yang tepat, dan f) evaluasi hasil belajar.

Pelaksanaan penelitian diawali dengan orientasi model self-directed learning yang akan dilaksanakan. Pada kegiatan ini disampaikan langkah-langkah pembelajaran, kontrak belajar, dan penilaian hasil belajar. Kegiatan pembelajaran di kelas diawali dengan langkah preplanning, yaitu guru menyampaikan pokok bahasan dan indikator ketercapaian, menampung berbagai masalah yang dihadapi siswa pada pembelajaran sebelumnya, dan mengingatkan materi sebelumnya yang terkait dengan pokok bahasan yang akan dibelajarkan melalui pertanyaan lisan.Guru berupaya menciptakan lingkungan belajar yang positif dengan cara membangkitkan motivasi belajar serta menyiapkan siswa untuk belajar. Pada langkah mengembangkan rencana pembelajaran, guru memberikan anjuran dan beberapa gambaran permasalahan yang nantinya dapat dikembangkan oleh siswa dalam pembelajaran.

Guru kemudian mendampingi siswa dalam menyusun rencana pembelajaran, baik secara mandiri atau berkolaborasi. Rencana pembelajaran yang disusun mencakup tujuan belajar, sarana belajar, target belajar, dan semua kegiatan yang berhubungan dengan tujuan belajar. Pada langkah mengidentifikasi aktivitas pembelajaran, siswa secara mandiri memilih dan mengidentifikasi strategi belajar serta mengidentifikasi aktivitas belajar yang relevan dengan target belajar yang ingin dicapai.

Guru dapat menawarkan aktivitas pembelajaran, keputusan memilih aktivitas belajar yang sesuai dengan dirinya ada pada siswa itu sendiri. Selanjutnya, guru dan siswa menyepakati kontrak belajar berdasarkan strategi belajar dan kriteria evaluasi yang dipilih. Setelah mengidentifikasi aktivitas pembelajaran, siswa mengimplementasikan strategi belajar yang telah dipilih. Mereka dapat belajar secara individu atau secara berkelompok dalam menyelesaikan permasalahan. Siswa memonitor pekerjaan dengan cara mencatat hal-hal yang dianggap penting serta masalah yang belum terpecahkan dan juga dapat mengulang sendiri materi yang dianggap sulit.

Guru mencermati kegiatan pembelajaran. Pada langkah mengevalusi hasil belajar, guru bersama siswa berdiskusi untuk memecahkan masalah yang belum terselesaikan, dan dilanjutkan dengan mengkolaborasikan pengetahuan yang diperoleh siswa. Di akhir pembelajaran, siswa mengevaluasi kegiatan belajar yang telah dilakukan kemudian melakukan pembenahan terhadap kesalahan dan kekurangan 
Setelah melakukan penelitian, didapatkan bahwa rata-rata hasil belajar ekonomi kelompok eksperimen sebesar 87,75. Rata-rata hasil belajar ekonomi kelompok kontrol sebesar 82,4. Ini berarti rata-rata hasil belajar matematika kelompok eksperimen lebih tinggi dibandingkan rata-rata hasil belajar ekonomi kelompok kontrol.

Untuk mengetahui tingkat perbedaan hasil belajar peserta didik yang menggunakan model pembelajaran Mandiri pada mata pelajaran ekonomi pada kompetensi dasar konsep manajemen pada pengukuran awal (Pretest) dan pengukuran akhir (Postest) di kelas eksperimen dapat dilihat dari nilai pretest dan posttest.

Tabel 2. Rekapitulasi Hasil Penelitian di kelas yang menggunakan Model Pembelajaran Mandiri

\begin{tabular}{cccccccc}
\hline Kelas Eksperimen & Mean & Standar Deviasi & Dk & $\mathrm{a}$ & $\mathrm{t}_{\text {hitung }}$ & $\mathrm{t}_{\text {tabel }}$ & HasilHipotesis \\
\hline Pretest & 32,5 & 12,74 & \multirow{2}{*}{70} & \multirow{2}{*}{0,05} & \multirow{2}{*}{1,69} & \multirow{2}{*}{ 12,44 } & $\begin{array}{c}\text { Ha :Diterima } \\
\text { Ho: Ditolak }\end{array}$ \\
Posttest & 87,75 & 4,24 & & & &
\end{tabular}

Berdasarkan Tabel 2 di atas, maka dapat diketahui bahwa nilai thitung sebesar 12,44 sedangkan nilai $t_{\text {tabel }} 1,67$ dengan nilai derajat kebebasan (dk) sebesar 70 dengan taraf kepercayaan $95 \%$ atau taraf signifikansi 0,05 . Hal tersebut menunjukan bahwa $t_{\text {hitung }}>t_{\text {tabel }}(12,44>1,67)$, maka hipotesis diterima, artinya terdapat perbedaan yang signifikan hasil belajar peserta didik yang mendapatkan model pembelajaran Mandiri (Self Directed Leaning) pada pengukuran awal (pretest) dan pengukuran akhir (posttest) di kelas eksperimen.

Tabel 3.Rekapitulasi Hasil Penelitian di kelas yang menggunakan Model Pembelajaran Konvensional

\begin{tabular}{cccccccc}
\hline Kelas Kontrol & Mean & Standar Deviasi & Dk & $\mathrm{a}$ & $\mathrm{t}_{\text {hitung }}$ & $\mathrm{t}_{\text {tabel }}$ & HasilHipotesis \\
\hline Pretest & 32 & 11,17 & & & & & Ha :Diterima \\
Posttest & 82,4 & 4,41 & 68 & 0,05 & 25,07 & 1,69 & Ho:Ditolak \\
\hline
\end{tabular}

Berdasarkan Tabel 3 di atas, maka dapat diketahui bahwa nilai thitung sebesar 25,07 sedangkan nilai ttabel 1,69 dengan nilai derajat kebebasan (dk) sebesar 68 dengan taraf kepercayaan $95 \%$ atau taraf signifikansi 0,05 . Hal tersebut menunjukan bahwa thitung $>$ ttabel $(25,07>1,69)$, maka hipotesis diterima, artinya terdapat perbedaan yang signifikan hasil belajar peserta didik yang mendapatkan model pembelajaran konvensional pada pengukuran awal (pretest) dan pengukuran akhir(posttest) di kelas kontrol.

Tabel 4. Rekapitulasi Hasil Penelitian di kelas yang menggunakan Model Pembelajaran Mandiri dan Model Pembelajaran Konvensional

\begin{tabular}{cccccccc}
\hline Kelas & Mean & Standar tDeviasi & Dk & a & thitung & $T_{\text {tabel }}$ & Hasil Hipotesis \\
\hline Eksperimen & 87,75 & 4,24 & & & & & Ha :Diterima \\
Kontrol & 82,4 & 4,41 & 69 & 0,05 & 5,24 & 1,67 & Ho: Ditolak \\
\hline
\end{tabular}

Berdasarkan Tabel 4 di atas, maka dapat diketahui bahwa nilai $t_{\text {hitung }}$ sebesar 5,24 sedangkan

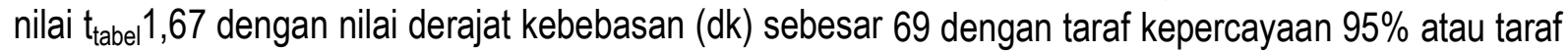
signifikansi 0,05 . Hal tersebut menunjukan bahwa $t_{\text {hitung }}>t_{\text {abel }}(5,24>1,67)$, maka hipotesis diterima, artinya terdapat perbedaan yang signifikan hasil belajar peserta didik yang mendapatkan model pembelajaran Mandiri (Self Directed Learning) dengan hasil belajar siswa yang mendapatkan model pembelajaran konvensional.

\section{PEMBAHASAN}

Masalah dalam penelitian ini adalah proses pembelajaran yang diterapkan selama ini mengabaikan gaya belajar yang ada pada setiap siswa sehingga belum berhasil meningkatkan kualitas 
proses yang pada akhirnya bermuara pada hasil belajar dan kemandirian belajar yang belum optimal. Setelah melibatkan siswa sebagai penentu arah pembelajaran dalam proses pembelajaran, diperoleh skor rata-rata 87,75 .

Untuk pembahasan perbedaan hasil belajar siswa yang menggunakan metode pembelajaran mandiri diperoleh nilai rata-rata hasil belajar pada pengukuran awal (pretest) sebesar 32,5 dan pada pengukuran akhir (posttest) diperoleh nilai rata-rata 87,75. Sehingga diperoleh selisih sebesar 55,25 atau jika dipersentasekan sebesar $56,96 \%$.

Dari perhitungan diperoleh nilai thitung sebesar 24,45 hasil tersebut kemudian dibandingkan dengan nilai tabel sebesar 1,67 dengan taraf kepercayaan 95\% atau taraf signifikansi 0,05 dengan derajat kebebasan (dk) sebesar 70 sehingga nilai thitung $>t_{\text {tabel }}$ atau $24,45>1,67$. Dengan demikian hasil perhitungan menunjukan bahwa terdapat perbedaaan yang signifikan pada hasil belajar peserta didik yang menggunakan model pembelajaran Mandiri dari pengukuran awal (pretest) ke pengukuran akhir (posttest).

Hasil tersebut menunjukan bahwa model pembelajaran Mandiriberpengaruh dalam meningkatkan hasil belajar peserta didik. Model pembelajaran Mandiri lebih mengaktifkan suasana belajar di dalam kelas, peserta didik lebih berperan aktif dalam proses pembelajaran karena diberi kesempatan untuk berfikir lebih maju, mengungkapkan pendapat, berdiskusi bersama kelompoknya.

Untuk pembahasan kedua perbedaan hasil belajar siswa yang menggunakan metode pembelajaran konvensional diperoleh nilai rata-rata hasil belajar peserta didik pada pemgukuran awal (pretest) sebesar 32 dan pada pengukuran akhir (posttest) sebesar 82,4 sehingga diperoleh selisih sebesar 50,4 atau jika di persentasikan sebesar $62,58 \%$.

Dari perhitungan diperoleh nilai thitung sebesar 25,07 hasil tersebut kemudian di bandingkan dengan nilai tabel sebesar 1,669 dengan taraf kepercayaan 95\% atau taraf signifikansi 0,05 dengan derajat kebebasan (dk) sebesar 68 sehingga nilai thitung $>t_{\text {tabel }}$ atau 25,07 $>1,669$. Dengan demikian hasil perhitungan menunjukan bahwa terdapat perbedaan yang signifikan pada hasil belajar peserta didik yang menggunakan metode pembelajaran konvensional dari pengukuran awal (pretest) ke pengukuran akhir (posttest).

Berdasarkan hasil perhitungan yang telah dilakukan dapat ditarik kesimpulan bahwa kelas yang menggunakan metode pembelajaran konvensional dapat juga meningkatkan hasil belajar peserta didik. Namun peningkatannya tidak sebanyak yang menggunakan model pembelajaran Mandiri (Self Directed Learning). Dalam metode pembelajaran konvensional peserta didik kurang berperan aktif dalam proses pembelajaran, proses pembelajaran masih terpaku pada guru dan peserta didik berperan pasif pada saat proses pembelajaran.

Untuk pembahasan ketiga perbedaan hasil belajar yang menggunakan model pembelajaran mandiri dengan model pembelajaran konvensional. Berdasarkan hasil pengujian hipotesis telah di ketahui bahwa model pembelajaran Mandiri (Self Directed Learning)yang diterapkan di kelas eksperimen lebih tinggi dan menghasilkan nilai akhir yang lebih tinggi dibandingkan metode pembelajaran konvensional yang di terapkan di kelas kontrol. Hal ini di buktikan dengan nilai rata-rata pengukuran akhir (posttest) di kelas eksperimen sebesar 87,75 sedangkan di kelas kontrol sebesar 82,4 . Sehingga diperoleh selisih sebesar 5,53 atau jika di prosentasikan sebesar 6,36\%.

Dari perhitungan diperoleh nilai 5,24 hasil tersebut kemudian dibandingkan dengan nilai $t_{\text {tabel }}$ sebesar 1,669 dengan taraf kepercayaan 95\% atau taraf signifikansi 0,05 dengan derajat kebebasan (dk) sebesar 69 sehingga nilai thitung $>t_{\text {tabel }}$ atau 5,24 >1,669. Dengan demikian hasil perhitungan menunjukan bahwa terdapat perbedaan yang signifikan pada hasil belajar peserta didik yang menggunakan model pembelajaran Mandiri (Self Directed Learning)dengan metode pembelajaran konvensional pada pengukuran akhir (posttest).

Berdasarkan hal-hal di atas dapat disimpulkan bahwa model pembelajaran Mandiri (Seld Directed Learning) memiliki pengaruh yang kuat dalam meningkatkan hasil belajar peserta didik. Walau demikian, kelas yang menggunakan metode pembelajaran konvensional juga dapat meningkatkan hasil 
belajar pesrta didik, namun pengaruhnya tidak terlalu besar. Dalam model pembelajaran Mandiri (Self Directed Learning) peserta didik lebih berperan aktif di dalam pembelajaran, sedangkan dalam model pembelajaran peserta didik lebih berperan pasif.

\section{KESIMPULAN}

Berdasarkan hasil penelitian dan pembahasan yang penulis sajikan, dapat ditarik beberapa kesimpulan sebagai berikut:

1. Terdapat perbedaan hasil belajar siswa yang menggunakan model pembelajaran Mandiri (Self Directed Learning) pada pengukuran awal (pretest) dan pengukuran akhir (post test) di kelas eksperimen.

2. Terdapat perbedaan hasil belajar siswa yang menggunakan model pempelajaran Konvensional pada pengukuran awal (pretest) dan pengukuran akhir (post test) dikelas kontrol.

3. Terdapat perbedaan hasil belajar siswa yang menggunakan model pempelajaran Mandiri (Self Directed Learning) dengan siswa yang menggunakan metode konvensional pada pengukuran awal (pretest) dengan pengukuran akhir (post test).

\section{REKOMENDASI}

Beberapa saran diajukan berdasarkan temuan peneliti, yaitu:

1. Dalam pembelajaran model pembelajaran Mandiri (Self Directed Learning) sebaiknya menjadi alternatif yang dipilih oleh pendidik dalam proses pembelajaran dengan syarat harus memperhatikan beberapa faktor, seperti situasi kelas, media pembelajaran yang ada di kelas, kesiapan peserta didik, jam pelajaran, dan materi yang akan di ajarkan.

2. Apabila dalam pembelajaran pendidik menerapkan metode konvensional, pendidik harus menyelipkan sedikit humor, menampilkan video motivasi setelah pembelajaran, menyelipkan sedikit permainan agar peserta didik tidak merasa jenuh dan bosan.

3. Bagi yang berminat melakukan penelitian lebih lanjut mengenai model pembelajaran Mandiri (Self Directed Learning) hendaknya memperhatikan dan memilih materi agar cocok diterapkannya model pembelajaran Mandiri (Self Directed Learning).

\section{UCAPAN TERIMA KASIH}

Ucapan terima kasih ini penulis sampaikan pula kepada:

1. Ketua dan Sekretaris Program Studi Pendidikan Akuntansi.

2. Para Dosen dan Staf Administrasi di Lingkungan Program Studi Pendidikan Akuntansi.

3. Bapak Wawan Kuswanda, SE selaku Guru Mata Pelajaran Ekonomi Kelas X SMA Negeri 1 Cisaga yang telah membantu dalam penelitian yang telah dilakukan.

\section{DAFTAR PUSTAKA}

Beratha. (2009). Pengaruh Model Self Directed Learning Terhadap Kemandirian Belajar Siswa Kelas VIII SMP Negeri 1 Gianyar Tahun Pelajaran 2008/2009.Skripsi (tidak diterbitkan). Singaraja: Universitas Pendidikan Ganesha.

Harsono. (2012). Pengertian Model Pembelajaran Self Directed Learning. Tersedia pada (https://pusat pengembanganpendidikan universitas gadjah mada.html)

Rusman. (2012). Model Model Pembelajaran Mengembangkan Profesionalisme Guru, Jakarta: Rajawali Pers

Slameto. (2010). Belajar dan factor-faktor yang mempengaruhinya. Jakarta: Rineka Cipta. 
Slameto. (2018). Belajar dan Faktor yang Mempengaruhinya. Jakarta: Rineka Cipta.

Sopiah, E, S., Effendi, A., \& Sunaryo, Y. (2020). Analisis Kemampuan Berpikir Kreatif Matematis Siswa Kelas VIII pada Materi Sistem Persamaan Linear Dua Variabel (SPLDV). J-KIP (Jurnal Keguruan dan IImu Pendidikan), 1 (2), 1-10.

Sudjana, N. 2016. Penilaian Hasil Proses Belajar Mengajar. Bandung: PT Remaja Rosdakarya.

Sugiyono. (2016). Metode Penelitian Pendidikan. Bandung: Alfabeta CV.

Sunarto, A. (2008). Perkembangan Peserta Didik. Jakarta : Rineka Cipta. 
